УДК 35.071

https://doi.org/10.52058/2708-7530-2021-9(15)-21-29

Бурик Зоряна Михайлівна доктор наук з державного управління, доцент, професор кафедри публічного управління та бізнес-адміністрування, Інститут післядипломної освіти та довузівської підготовки Прикарпатського національного університету ім. В. Стефаника, вул. Шевченка, 57, м. ІваноФранківськ, 76018, тел.: (0342) 75-23-51, e-mail: z.burik@ukr.net, https://orcid.org/0000-0002-4394-6766

\title{
ЕКСПЕРТНІ ДОСЛІДЖЕННЯ В ПУБЛІЧНОМУ УПРАВЛІННІ
}

Анотація. У статті розглянуто поняття публічного управління та особливості проведення експертних досліджень у цій сфері. Зважаючи на те, що основним прийомом, який використовується при експертних дослідженнях $\epsilon$ опитування, зазначені у дослідженні види опитувань $\epsilon$ актуальними. Однією 3 характерних особливостей експертного дослідження $\epsilon$ можливість його проведення професіоналами конкретної галузі, у тому числі експертами в галузі публічного управління. Будь-яке експертне дослідження проводиться поетапно, у відповідності до тієї послідовності дій, яка визначена як базова, але характерною відмінністю експертного дослідження у сфері публічного управління $\epsilon$ те, що критерії, за якими проводиться експертна оцінка під час експертного дослідження, визначаються перед початком його проведення та закладаються у текст анкети, результати якої піддаються оцінюванню. Встановлено, що оцінка ефективності публічного управління здійснюється різними способами, але одним iз найбільш ефективних прийомів $є$ експертні дослідження. Визначено, що експертні дослідження проводяться фахівцями, які мають відповідну освіту, кваліфікаційний рівень та володіють відповідним набором компетенцій. 3'ясовано, що при проведенні експертних досліджень, основним інструментарієм $\epsilon$ опитування, які, у більшості випадків, пропонуються респондентам у формі анкет. Питання для анкети складаються одним експертом або командою експертів. При складанні питань експерти дотримуються двох ключових аспектів: функціонального та цільового. Критерії оцінювання результатів експертного дослідження визначаються групою експертів та на основі рівня спорідненості висновків різних експертів робиться узагальнення. У випадку, коли рівень спорідненості експертів незначний, постає питання відповідності їх званню експерта у цьому питанні, а за високого показника спорідненості ведеться мова про достовірність отриманих результатів експертного дослідження.

Ключові слова: експертні дослідження, експертна оцінка, публічне управління. 
Buryk Zoryana Mykhailivna Doctor of science in public administration, Associate Professor, Professor of Public Administration and Business Administration, Institute of Postgraduate Education and Pre-University Training, Prykarpattia National University them. V. Stefanika, Shevchenko St., 57, Ivano-Frankivsk, 76018, tel.: (0342) 75-23-51, e-mail: z.burik@ukr.net, https://orcid.org/0000-0002-4394-6766

\section{EXPERT RESEARCH IN PUBLIC ADMINISTRATION}

Abstract. The article considers the concept of public administration and features of expert research in this area. Due to the fact that the main technique used in expert research is surveys, the types of surveys mentioned in the study are relevant. One of the characteristic features of expert research is the possibility of its conduct by professionals in a particular field, including experts in the field of public administration. Any expert study is conducted in stages, in accordance with the sequence of actions, which is defined as basic, but the characteristic difference of expert research in the field of public administration is that the criteria for expert evaluation during the expert study are determined before it and are included in the text of the questionnaire, the results of which are subject to evaluation. It is established that the assessment of the effectiveness of public administration is carried out in different ways, but one of the most effective methods is expert research. It is determined that expert research is conducted by specialists who have the appropriate education, qualification level and have the appropriate set of competencies. It was found that in conducting expert research, the main tools are surveys, which, in most cases, are offered to respondents in the form of questionnaires. The questions for the questionnaire are compiled by one expert or a team of experts. When compiling questions, experts adhere to two key aspects: functional and target. Criteria for evaluating the results of expert research are determined by a group of experts and based on the level of similarity of the conclusions of different experts, a generalization is made. In the case when the level of kinship of experts is insignificant, there is a question of compliance with their title of expert in this matter, and with a high rate of kinship - we are talking about the reliability of the results of expert research.

Keywords: expert research, expert evaluation, public administration.

Постановка проблеми. Пізнання загальних закономірностей розвитку суспільства дозволяє розробляти та впроваджувати нові технології, які активно використовуються в політиці, економіці, соціальній сфері. Наука входить практично у всі сфери людської діяльності, не лишаючи без уваги і таку галузь як публічне управління. Новітні теоретичні розробки, науково-практичні рекомендації які впроваджуються в даній галузі сприяють загальнодержавному, галузевому, та територіальному розвитку, надають можливість прийняття важливих рішень органами влади місцевого, регіонального або загального рівнів. Для досягнення високих показників у сфері державного управління, 
перед державними службовцями досить часто виникає потреба у проведенні досліджень прикладного характеру. Для проведення даних досліджень він може або використовувати власний досвід та провести дослідження самостійно, або звертається за такою послугою до науковців.

Зважаючи на те, що управлінська діяльність публічного характеру є одним із головних чинників, що сприяє розвитку сучасної держави, виникає потреба у проведенні ефективної оцінки публічної управлінської діяльності органів місцевого, регіонального або державного рівнів. Основу ефективної оцінки становить експертне дослідження, яке спрямоване на визначення особливостей публічної управлінської діяльності. Експертне дослідження та експертна оцінка дозволяють суспільству здійснювати контроль за діяльністю державних інститутів, а керівникам державних установ - за роботою державних службовців.

Успішне проведення наукового дослідження в галузі публічного управління $\epsilon$ можливим лише за тієї умови, коли державний службовець, або науковець, який проводить експертне дослідження, володіє відповідним методологічним інструментарієм, вміє доцільно i раціонально його використовувати 3 урахуванням специфіки галузі публічного управління.

Аналіз останніх досліджень і публікацій. У сучасному світі дослідження особливостей публічного управління набуло значного поширення. Так в різні часи проблеми публічного управління досліджували Бакуменко В., Білинська М., Надолішній П., Бровікова С., Петроє О., Новікова В., Іжа М., Оболенський О., Савков А., Шатило О., Шемшученко Ю. та інші. Проблематику організації та проведення соціологічних досліджень висвітлювали Титаренко О., Верцімага I., Толстих Н., Литвак Б., Добреньков В., Кравченко А., Ельмеєв В. [6], Овсянников В. та інші. Особливої уваги в аспекті проведення соціологічних експертних досліджень заслуговують праці Дворецької Г.[4], яка описує особливості методу анкетування, визначаючи його переваги та недоліки, та зазначає, що цей метод дозволяє отримати найбільш об'єктивні результати дослідження. Брайченко О., Саченко Т., Коняшина Н. зазначають, що ефективним методом для збору та обробки цифрових даних є моніторинг. Даний метод є комплексним і дозволяє використовувати прийоми опитування для визначення первинної інформації та використовувати ii для подальшого планування дій, спрямованих на вирішення виявлених проблем [2]. Досліджувала аспекти анкетування і Лукіна Ю., але, на відміну від своїх попередників, вона пропонує використовувати його на етапі збору інформації при проведенні моніторингових досліджень. Лукіна Ю. зазначає, що ефективним можна вважати те анкетування, під час проведення якого респондент власноручно заповнює запропонований йому бланк із запитаннями анкети. Також вона відмічає, що лише за умови проведення великої кількості досліджень у сфері публічного управління можна досягнути високих показників в управлінській діяльності [11].

Оцінка ефективності публічно-державного управління на різних рівнях 
влади проводилась такими дослідниками як Ведунг Е., Вольська О., Дербетова [5] Т., Каплан Р., Нортон Д., Коавчук І., Мескон М., Неліпа М. та іншими.

Останнім часом в Україні проводиться чимало досліджень у різних галузях, зокрема у галузі ділового та публічного адміністрування, публічного управління. Саме тому експертні дослідження набувають провідного значення під час оцінки ефективності публічного управління.

Мета статті - визначити ефективні методи проведення досліджень, використання яких є доцільним у сфері публічного управління.

Виклад основного матеріалу. При визначенні особливостей експертних досліджень у сфері публічного управління, спочатку варто розкрити сутність поняття «публічного управління».

Щоб визначити його суть та науково-грунтовно проаналізувати його зміст, звернемось до етимології слова «публічний». «Публічний» походить від латинського «publicus» - суспільний, народний. В українському перекладі це слово також звучить як «людовий, народний, громадський, державний» [9, с. 860]. В словнику іншомовних слів публічний характеризується як «відкритий, гласний, суспільний» [14, с. 560]. В новому тлумачному словнику з української мови слово «публічний» має кілька інтерпретацій та значень: 1) той, що відбувається у присутності людей; 2) прилюдний, привселюдний, гласний, відкритий; 3) орієнтований на широке коло відвідувачів, користувачів; 4) громадський, загальний, загальнодоступний; 5) стосується публіки [12, с. 843].

Етимологічний словник української мови характеризує поняття «публіка» як «групу людей, яка зібралась в конкретному місці (глядачі, слухачі) в одній інтерпретації як народ» та пропонує перелік спільнокореневих слів: публікатор, публікація, публіцист, публіцистка, публічний, публіцистичний, публікувати [8, с. 625].

Деякі науковці-лексикографи замість терміну «публічний» використовують «публіка» (від лат. «publica» - суспільство, народ, люди), замінюючи їх синонімічними словами на основі визначеного ними синонімічного ряду: всенародний, явний, відомий, організований для публіки, суспільства, загальнонародний, все людний, такий, що належить всім [3, с. 535].

Звертаючись до українсько-англійського словника, зіштовхуємось із тим, що в перекладі 3 англійської «public» звучить як громадський, публічний, державний [14, с. 292]. У словнику юридичної термінології термін «публічний» зустрічається у ряді словосполучень, основними 3 яких $\epsilon$ «публічна влада», «публічне право», «публічне адміністрування» та інші [7, с. 196-198].

Виходячи з усіх перелічених означень, можемо зробити висновок про те, що у всіх підходах «публічний» означає відкритий, народний.

Характеризуючи поняття публічне управління, звертаємось до термінологічного словника 3 публічного управління, в якому даний термін характеризується як «діяльність органів державного управління, органів місцевого самоврядування, представників приватного сектору та інститутів 
громадянського суспільства в межах визначених законом повноважень i функціональних обов’язків (планування, організації, керівництва, координації та контролю) щодо формування та реалізації управлінських рішень суспільного значення, політики розвитку держави та ii адміністративно-територіальних одиниць». Зазначається в словнику і те, що публічне управління спрямоване на підвищення ефективності управлінської діяльності за рахунок підтримки та консолідації суспільства навколо спільних цілей, з урахуванням демократичних цінностей, принципів права верховенства, поваги та гідного ставлення до людини, недискримінаціі, рівності, справедливості, безпеки, ефективності тощо [13, с. 143].

На даному етапі розвитку України однією з актуальних проблем сьогодення $\epsilon$ визначення ефективності роботи органів публічного управління. Оцінку даної галузі, як правило, проводять експерти, які використовують для цього ряд досліджень різноманітного характеру, але базовим їх інструментарієм є опитування.

Доволі часто при проведенні досліджень у сфері публічного управління виникає потреба у застосуванні додаткових інформаційних джерел, які б дозволили підтвердити або спростовувати інформацію, яка вважалась сумнівною. Одним із джерел такої інформації можуть стати експерти, які проводять експертну оцінку.

Експерти - це спеціалісти, які мають необхідний набір знань, досвід роботи у певній галузі та володіють навичками аналізу інформації, яка до них надходить, вміють іiі оцінювати та надавати таку оцінку в межах своєї компетенції. Крім того, експерти повинні володіти технологіями, які використовуються у визначених сферах діяльності, здатні оцінювати ймовірність і доцільність використання таких технологій у конкретній управлінській ситуації, роблять висновки та надають відповідні рекомендації [10, с. 31].

Експертна оцінка - це ряд заходів, дій та дослідницьких процедур, які спрямовані на збір експертами інформації, іiі подальшу обробку, інтерпретацію, переставлення результатів експертного дослідження та вироблення управлінських та політичних рішень [7, с. 155].

При проведенні експертних досліджень, зокрема у сфері публічного управління, дотримуються певної послідовності дій:

1. Створення експертної групи. Експертна група яка буде працювати над даним експертним дослідженням повинна складатись 3 10-150 осіб, які $\epsilon$ провідними фахівцями у досліджуваній галузі. Перед даною групою осіб ставиться мета, визначаються завдання дослідження, яке на них покладено, терміни його проведення та надається перелік методів, які бажано використовувати. Обов'язково призначається відповідальна особа, яка буде звітувати перед організацією, яка замовляє експертне дослідження.

2. На другому етапі експерти визначають основні цілі i завдання опитування, яке планується, засоби, які будуть використовуватись для їх досягнення. 
3. Залежно від визначених цілей обирається метод опитування, який буде найбільш раціональним та дозволить отримати найбільш повні результати від запланованого опитування і лише після цього складається анкета. Третім етапом $є$ складання анкети. Традиційною формою анкети $є$ таблиця, в якій міститься перелік питань, що розміщуються в певній ієрархічній послідовності (першими йдуть прості питання, останні можуть вимагати розгорнутої відповіді). Форма питань визначається експертами. Основу, у більшості випадків, складають питання закритого типу із вибором однієї із запропонованих відповідей, але можуть бути і питання, які вимагають коментарів експертів.

4. Розрахунок експертних оцінок. Даний розрахунок проводиться на основі отриманих результатів анкетування та з урахуванням такого показника як узгодженість індивідуальних оцінок експертів. У випадку високої узгодженості отримані показники синтезуються та використовуються для подальшого прогнозування, висування гіпотез, пошуку можливих варіантів вирішення виявлених проблем. Якщо ж рівень узгодженості оцінок експертів низький, то варто провести оцінку рівня професійної компетентності експертів у досліджуваному аспекті та змінити склад експертної комісії [1].

Не дивлячись на те, що існує певний механізм, який використовують при проведенні експертної оцінки, як зазначають фахівці, єдиної методики, яку б можна було назвати універсальною для отримання експертної оцінки, не існує. Методичні прийоми, які використовуються, базуються на принципах опитування, яке може виявлятись у таких формах:

- $\quad$ разове індивідуальне опитування (анкетування або інтерв'ю);

- разове опитування певного колективу (дискусія, нарада, мозкова атака);

(дельфійський метод);

- $\quad$ колективне опитування, яке проводиться в кілька етапів (дискусія, нарада, багаторівневе експертне опитування) [16].

Метод експертного опитування використовують для виявлення найбільш суттєвих проблем, складних аспектів досліджуваної проблеми, підтвердженні достовірності i надійності зібраної інформації, використанні зроблених в результаті опитування експертами висновків та наданих практичних рекомендацій. Але застосування методу експертної оцінки раціональним $є$ лише тоді, коли отримані результати можна співставити з об'єктивними даними або 3 інформацією, яка була зібрана іншим способом [15].

Експертна оцінка ефективності публічного управління грунтується на тому, що отримані під час опитування результати піддаються співставленню із результатами інших досліджень та порівнюються за рядом критеріїв. Процедура оцінювання спрямована на виявлення об'єктивних та суб'єктивних чинників процесу публічного управління. Як правило, критерії, якими користуються експерти під час експертної оцінки, є непостійними і можуть варіювати залежно 
від того, яке саме експертне оцінювання здійснюється.

Експертна оцінка, яка надається публічному управлінню в разі проведення експертного дослідження, здійснюється комплексно, 3 урахуванням двох ключових аспектів: цільового та функціонального.

Цільовий аспект - це аспект, який повноцінно спрямований на оцінку ефективності 3 урахуванням динамічних показників, що відображають просування до нормативно-правових значень соціально-економічного розвитку 3 урахуванням критерію «витрати-результати». Під час формування анкети показниками, які враховуються при оцінюванні, повинні виступати:

- просування аспектів публічного управління в напрямі цілей, визначених як провідні;

- динаміка просування із урахуванням критерію соціальноекономічного розвитку;

- дотримання чинних обмежень у галузі екології та соціології;

- ефективне зростання ВВП;

- $\quad$ показник рівня якості життя населення;

- $\quad$ ефективність програм та проєктів, які були реалізовані владою.

Функціональний аспект спрямований на оцінку ефективності показника якості виконання основних функцій управління i тих умовах, в яких таке управління здійснюється. Базовими критеріями, які враховуються при складанні питань анкети, є:

- показник якості системи стратегічного планування та цільового управління;

- наявність відповідного законодавчого та нормативно-правового забезпечення;

- оцінка якості ефективності роботи функціональних підрозділів цільового планування та управління;

- сформованість та дієвість системи соціально-економічної та інформаційно-аналітичної оцінки ситуації, яка підлягає дослідженню;

- наявність системи, відповідно до якої здійснюється підготовка та перекваліфікації працівників сфери публічного управління $[16 ; 17]$.

Як правило, після формування основних питань анкети та отримання результатів експертного дослідження, визначаються критерії оцінювання, які надаються для роботи всій команді експертів, або кожному з експертів окремо. Формування критеріїв ефективності публічного управління здійснюється на базі системи суб'єктивних цінностей, які знаходять своє відображення в ідеології суспільно-державного устрою, в політичних та стратегічних курсах суб'єкта правління, визначених у чинних нормах управління за якими стоять державні інтереси, визначені на загальному рівні.

Висновки. Публічне управління, це сфера управлінської діяльності, яка визначається органами державного управління на рівні місцевого 
самоврядування або представників приватного сектору, інститутів громадянського суспільства, діяльність яких має суспільне значення та спрямована на політику розвитку держави або окремих адміністративнотериторіальних одиниць.

Оцінка ефективності публічного управління здійснюється різними способами, але одними із найбільш ефективних прийомів $\epsilon$ експертні дослідження. Експертні дослідження проводяться фахівцями, які мають відповідну освіту, кваліфікаційний рівень та володіють відповідним набором компетенцій. При проведенні експертних досліджень основним інструментарієм $\epsilon$ опитування, які, у більшості випадків, пропонуються респондентам у формі анкет. Питання для анкети складаються одним експертом або командою експертів. При складанні питань експерти дотримуються двох ключових аспектів: функціонального та цільового.

Критерії оцінювання результатів експертного дослідження визначаються групою експертів та на основі рівня спорідненості висновків різних експертів робиться узагальнення. У випадку, коли рівень спорідненості експертів незначний, постає питання відповідності їх званню експерта у даному питанні, за високого показника спорідненості - ведуть мову про достовірність отриманих результатів експертного дослідження.

\section{Лimepamypa:}

1. Башинська I. Використання методу експертних оцінок у економічних розрахунках // Актуальні проблеми економіки. - 2015. - №7 (169). - С. 408-412.

2. Брайченко О.Д., Саченко Т.А., Коняшина Н.А. Моніторинг особистісних потреб управлінських кадрів як один із шляхів забезпечення ефективності їх професійного розвитку: навч.-метод. Матеріали. Київ: НАДУ, 2013. - 56 с.

3. Даль В.И. Толковый словарь живого великого русского языка: в 4 т. В.И. Даль. М.: Рус. яз. 1999. Т. 3: П, 1999. - 555 с.

4. Дворецька Г.В. Соціологія: навч. посіб. Київ: КНЕУ, 1999. - 340 с.

5. Дербетова Т.Н. Оценка эффективности государственного управления: от общих подходов к конкретно-предметным Интернет-журнал «Науковедение», 2012. Режим доступу: http://cyberleninka.ru/article/n/otsenka-effektivnosti-gosudarstvennogo-upravleniyaot-obschihpodhodov-k-konkretno-predmetnym.

6. Ельмеев В.Я. Прикладная социология: Очерки методологии. Режим доступу: http://society.polbu.ru/elmeev_sociology/ch32_i.html.

7. Енциклопедія державного управління: у 8 т. / Нац. акад. держ. упр. при Президентові України; наук.-ред. колегія: Ю.В. Ковбасюк (голова) та ін. Т. 2: Методологія державного управління / наук.- ред. колегія: Ю.П. Сурмін (співголова), П.І. Надолішний (співголова) та ін. 2011. $-692 \mathrm{c}$.

8. Етимологічний словник української мови: у 7 т. Ред. кол.: О.С. Мельничук (голов. ред. та ін.; уклад. Р.В. Болдирєв та ін., ред. В.Т. Коломієць, В.Г. Скляренко). К.: Наук. думка, 1983. Т. 4. 2003. - 656 с.

9. Кобилянський Ю. Латинсько-український словар для середніх шкіл. Відень, 1912. $660 \mathrm{c}$.

10. Литвак Б.Г. Экспертные технологии в управлении: учебное пособие. 2-е изд., испр. и доп. Москва: Дело, 2004. - 400 с. 
11. Лукіна Т.О. Технологія управління якістю освіти державних службовців: метод. посібн. для системи підвищення кваліфікації. Луцьк, 2010. - 50 с.

12. Новий тлумачний словник української мови: у 4 т. 42000 слів / уклад.: В. Яременко, О. Сліпушко. К.: Аконіт, 2000. Т. 3. - 927 с.

13. Публічне управління: термінол. слов. / уклад.: В.С. Куйбіда. Київ: НАДУ, 2018. - 224 с.

14. Словник іншомовних слів / за ред. чл. кор. АН УРСР О.С. Мельничука. К., 1977. - 775 с.

15. Таньчук О.А. Основні підходи до оцінювання ефективності публічного управління // Вісник НАДУ - 2015. - №3. - С. 63-70.

16. Толстих Н.В. Експертні опитування. Режим доступу: http://isoc.com.ua/school/Tolstyh_Expert.pdf.

17. Стрюков, В. (2020). УПРАВЛІННЯ ПРОЦЕСОМ ФОРМУВАННЯ КОМУНІКАТИВНОЮ КОМПЕТЕНЦІЕЮ СЕРЕДНЬОГО МЕДИЧНОГО ПЕРСОНАЛУ. Економіка та суспільство, (22). https://doi.org/10.32782/2524-0072/2020-22-58

\section{References:}

1. Bashyns'ka, I. (2015). Using the method of expert assessments in economic calculations [The use of the method of expert assessments in economic calculations]. Actual problems of economy - Actual problems of economics, 7 (169), 408-412 [in Ukrainian].

2. Braichenko, O.D., Sachenko, T.A., \& Konyashina, N.A. (2013). Monitoring of personal needs of managerial staff as one of the ways to ensure the effectiveness of their professional development: teaching method. Materials. Kyiv: NAPA [in Ukrainian].

3. Dal, V.I. (1999). Explanatory dictionary of the living great Russian language: in 4 volumes. Moscow: Rus. yaz., 3. [in Russian]

4. Dvoretska, G.V. (1999 ).Sociology: Navch. PosibNik. Kyiv: KNEU. [in Ukrainian].

5. Derbetova, T.N. (2012). Assessment of the effectiveness of public administration: from general approaches to specific-subject. Internet-journal «Science of Science». Retrieved from http://cyberleninka.ru/article/n/otsenka-effektivnosti-gosudarstvennogo-upravleniyaot-obschihpodhodov-k-konkretno-predmetnym [in Ukrainian].

6. El'meev, V.Ja. Prikladnaja sociologija: Ocherki metodologi. Retrieved from http://society.polbu.ru/elmeev_sociology/ch32_i.html [in Russian].

7. Entsyklopediia derzhavnoho upravlinnia: u 8 t. 2011. [in Ukrainian].

8. Boldyrev, R.V and others. (2003). Etymological dictionary of the Ukrainian language: in vols. Ed. Col Kyiv: Nauk. Dumka. [in Ukrainian].

9. Kobylyansky, J. (1912). Latin-Ukrainian dictionary for secondary schools. Vienna. [in Ukrainian].

10. Litvak, B.G. (2004). Jekspertnye tehnologii v upravlenii : uchebnoe posobie: 2-e izd., ispr. i dop. Expert technology in the management : schoolbook. Delo, Moscow [in Russian].

11. Lukina, T.O. (2010). Technology of quality management of education of civil servants: method. manual for the system of advanced training. Lutsk [in Ukrainian].

12. Yaremenko, V., \& Slipushko, O. (2000). New explanatory dictionary of the Ukrainian language: in 4 volumes 42000 words. Kyiv: Aconite [in Ukrainian].

13. Kuybida, V.S. (2018). Public administration: terminal. words. Kyiv: NAPA [in Ukrainian].

14. Mel'nychuk. K. (1977). Dictionary of foreign words Kyiv [in Ukrainian].

15. Tanchuk, O.A. (2015). Basic approaches to evaluating the effectiveness of public administration. Bulletin of NAPA, 3, 63-70 [in Ukrainian].

16. Tolstykh, N.V. Ekspertni opytuvannia. Retrieved from http://i-soc.com.ua/sc [in Ukrainian].

17. Strjukov, V. (2020). UPRAVLINNJa PROCESOM FORMUVANNJa KOMUNIKATIVNOJu KOMPETENCIEJu SEREDN"OGO MEDIChNOGO PERSONALU. Ekonomika ta suspil'stvo, (22). https://doi.org/10.32782/2524-0072/2020-22-58 